\title{
Experimental Investigation of Using PET Wastes as Tension Bars in Reinforced Concrete Beams
}

\author{
Abass Oda Dawood ${ }^{1} \quad$ Hamsa Mahir Adnan ${ }^{2}$ \\ ${ }^{1}$ Civil Engineering Department, Civil Engineering Department, College of Engineering, Misan \\ University, Misan, Iraq \\ abbasoda03@uomisan.edu.iq \\ ${ }^{2}$ Civil Engineering Department, College of Engineering, Misan University, Misan, Iraq \\ hamsamahir95@gmail.com
}

\begin{tabular}{|l|l|l|}
\hline Submission date:- 9/12/2018 & Acceptance date:- 6/2/2019 & Publication date:-12/2/2019
\end{tabular}

\begin{abstract}
This research is aimed to study the possibility of recycled the PET wastes by forming the PET wastes as plastic semi-bars and used it as tension bars in simply supported reinforced concrete beams . Twelve beams specimens with dimension of $(150 * 200 * 1400) \mathrm{mm}$ are casted and tested to monitoring the effecting of these wastes as tension bars on the strengths and serviceability of reinforced concrete beams. The mechanical properties (compressive, splitting tensile and flexural strength) are evaluated in which specimens tested in age of 28 days. The tests results showed that all presented plastic semi-bars are failed except one case in which the deformed steel bar are used with additional layer of PET bottle cut into two parts which showed an increment in ultimate failure load and deflection of $3.03 \%$ and $213.83 \%$ respectively, larger than the reference beam specimens. Negatively effect of PET semi-bar on ultimate load of beams is due to bonding failure between PET bars and surrounding concrete, which made the PET bars as voids or weak region within beam cross section.
\end{abstract}

Keywords: Polyethylene Terephthalate, PET wastes, Plastic semi-rebar, PET rebar, PET strip.

Journal of University of Babylon for Engineering Sciences by University of Babylon is licensed under a Creative Commons Attribution 4.0 International License. 


\section{1- Introduction}

The problem of plastic waste is a global problem, and is not confined to a particular country without another, but for all the countries of the world, with different degrees of seriousness. Plastic waste is one of main environmental problems facing Maysan province nowadays, these wastes are exposed to the elements of the environment such as soil, water and air pollution, and consequently lead to the depletion of natural resources. In the same time, the absence of correct ways for collection, transmission and processing of the plastic waste is complicated this problem. The cities of Iraq faced the problem of accumulation of solid waste in huge random phenomenon. It is filling the roads, streets and squares in nearby residential neighborhoods, or inside [1]. The use of potable water and other drinks is increasingly widespread in various sizes of plastic bottles, thus huge amounts of this product are dumped in waste containers and unfortunately, there are large amounts thrown in the streets, open areas, parks, forests and rivers [2]. One technique to reduce plastic waste impact on environment and reduce cost of disposal is recycled it in the form of construction material as replacement of sand or gravel or as fiber added to the concrete. There are many kinds of plastic waste reused in construction, but the most common type used by researchers is Polyethylene terephthalate (PET) as replacement of fine aggregates or added as fiber to the concrete mixture [3-9]. There is little researches available in literature related to reuse of PET waste bottles as reinforcement for concrete beams. Recycling PET waste bottles as plastic bars for tension reinforcement of concrete beams has been considered in some researches [10-13]. In 2010, Kim et al [10], utilized recycled PET fiber reinforced concrete and polypropylene PP fiber reinforced concrete as reinforcement for concrete beam. Their results showed that the fiber reinforced concrete had better crack resistance and strain hardening capacities than the specimens without fibers, and observed from load-deflection result that the maximum mid-span deflection is approximately $400 \%$ larger in the FRC than the specimens without fibers and the fibers enhanced tensile resistance and delayed macro-crack formation are showed. .In 2013, Foti et al [11], utilized PET fiber as discrete reinforcement of specimens added to the concrete in substitution of steel bars, where the fibers obtained by simply cutting the bottles. The PET bottles used with three forms in three tests one of them is the use of it in the circular form (circular fibers) with $5 \mathrm{~mm}$ width used in percentages of $(0.5,0.75,1.0) \%$ by weight of concrete and the second form is concrete beams reinforced with long PET strips (half bottle) in a position similar to the reinforcement bars in the concrete beams and the third form is substitution of steel reinforcement as strips cutting from bottles with dimensions $\left(45^{*} 0.2 * 300\right) \mathrm{mm}$. Their results showed that $1.0 \%$ is the best percentage of circular fibers. In 2014, Kumar et al [12] used recycled PET fiber as reinforcement for concrete beam in four parts of samples with steel bars, without steel bars, with PET reinforcement, and combined steel and PET reinforcement. The first type, the beams made with plain concrete without any reinforcement, the second type is beam reinforced with PET hollow bars $24 \mathrm{~mm}$ and $22.8 \mathrm{~mm}$ external diameter and internal diameter respectively, the third and fourth types are beams with combination of steel and PET reinforcement in the tension zone. The results showed that the fiber reinforced concrete with different types that improved in flexural strength. In 2014, Lopez et al [13], utilized recycled PET fibers cutting by special device as reinforcement for concrete beam with different fiber volume. The results showed that the fiber reinforced concrete with both short and continuous fibers had better flexural strength, ductile behavior and energy absorption capacity than the specimens without fibers. Thus in the present study new configurations and forms of reusing PET bottles as reinforcement for concrete beams in different forms are investigated.

\section{2- Experimental Work}

\subsection{Mixture proportioning}

For all beams, the concrete mixtures used in the present study consisted of $649.644 \mathrm{~kg} / \mathrm{m} 3 \mathrm{sand}$, $1024 \mathrm{~kg} / \mathrm{m} 3$ gravel, $495.12 \mathrm{~kg} / \mathrm{m} 3$ cement, and $201.38 \mathrm{~kg} / \mathrm{m} 3$ water with adding $3.961 \mathrm{~kg} / \mathrm{m} 3$ of super plasticizer as shown in Table.1. The water to cement ratio used of concrete mixture for all beams is 0.41 in which this mix proportion yield a slump of $200 \mathrm{~mm}$. The values of 28 days, compressive strength, split tensile strength and flexural strength tests are $35.8 \mathrm{MPa}, 3.1 \mathrm{MPa}$, and $4.53 \mathrm{MPa}$, respectively.

The experimental program aims to study the possibility of using plastic PET wastes as tension elements at the tension zone of simply supported reinforced concrete beam specimens. Different patterns for using PET bottle waste in concrete beams are used, either as main reinforcement bars, or surrounding 
steel rebar or as strips or sheets. Twelve concrete beams with various reinforcement ways are casted and compared with the reference beam to investigate it is effect on beam behavior.

Table 1 Constituents of the concrete mixture per cubic meter.

\begin{tabular}{cc}
\hline Materials & Dosage $\mathbf{~ k g} / \mathbf{m}^{3}$ \\
\hline Cement & 495.12 \\
Sand & 649.644 \\
Gravel & 1024 \\
Water & 201.38 \\
SP & 3.961 \\
\hline
\end{tabular}

\subsection{Description of Test Beams}

Wooden molds are utilized for casting all reinforced concrete beams, as shown in Fig.1. All molds consist of a wooden base and four moving sides that connect with each other and with the base by bolts and screws. The beam is simply supported with span length $1400 \mathrm{~mm}$ and the cross section is rectangular $(\mathrm{b} \times \mathrm{h}=150 \times 200 \mathrm{~mm})$.
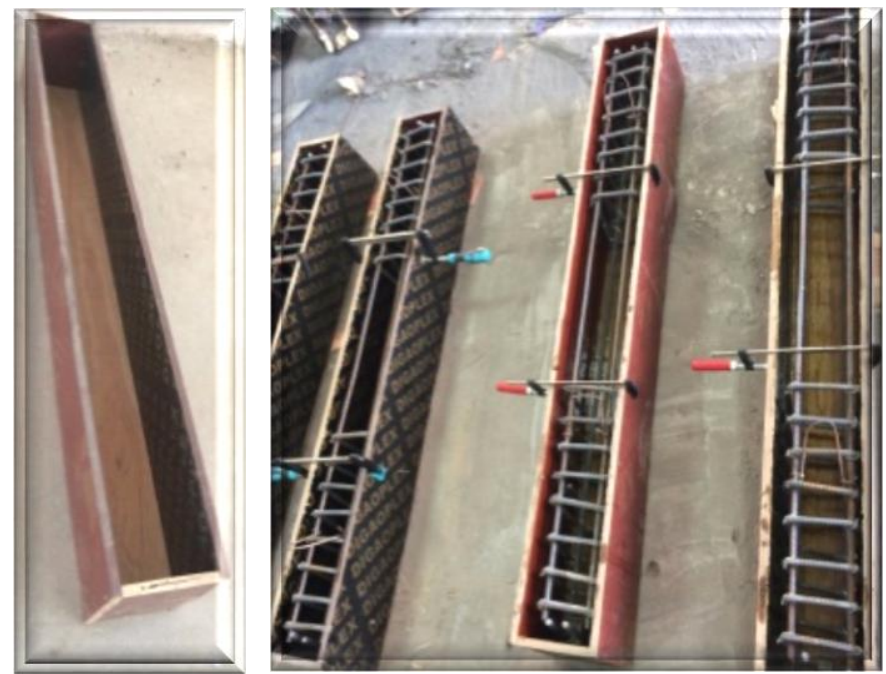

Figure 1 Beam molds and reinforcement.

Twelve reinforced concrete beams are tested in this study, with different arrangements of reinforcement. Some beams are reinforced with deformed steel rebar, as shown in Fig.2, which include two bars \#13 (12.7 mm diameter) as tension reinforcement, stirrups reinforcement \#10 (9.5 mm diameter) at 60 $\mathrm{mm} \mathrm{c} / \mathrm{c}$ and two bars \#10 $\mathrm{mm}$ as anchorage bars to fix the stirrups. Other beams are reinforced with PET bottle as partial or fully reinforcement.

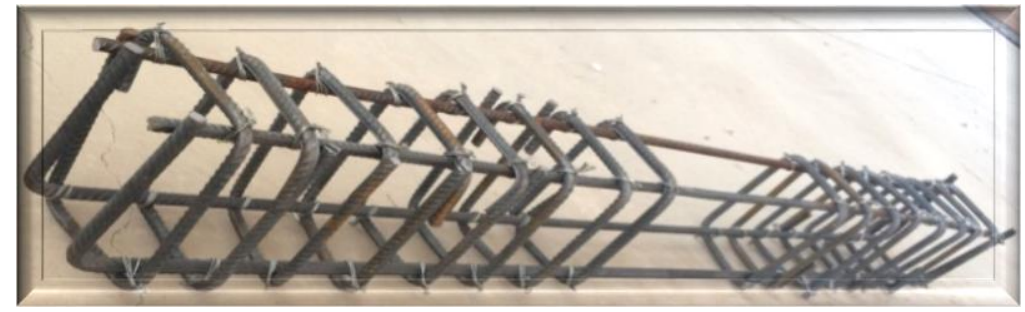



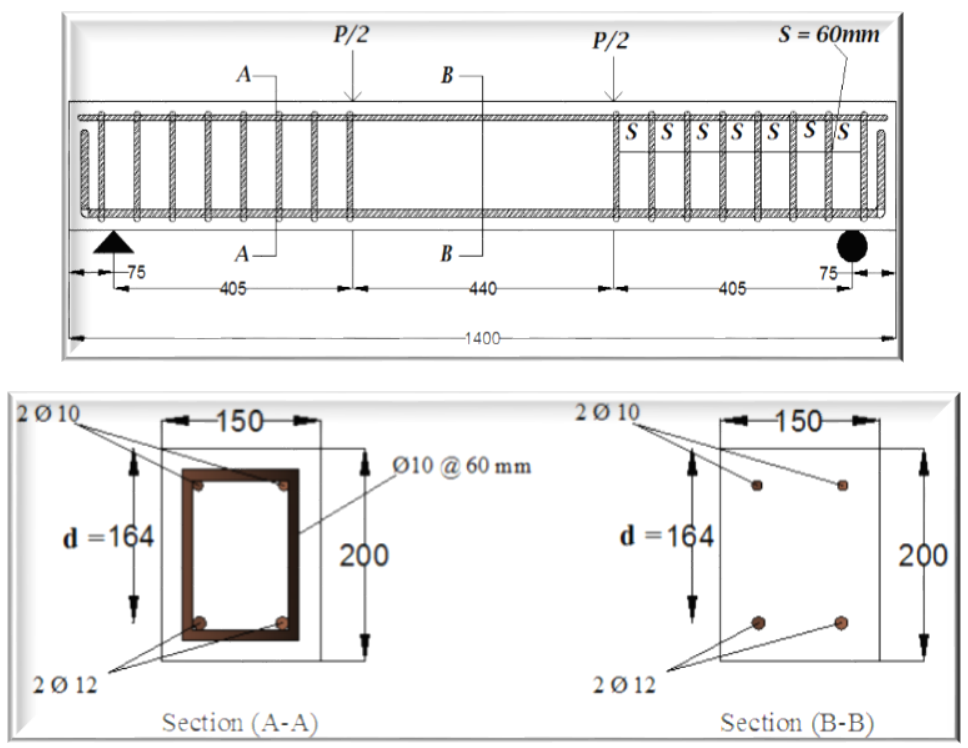

Figure 2 Dimensions and reinforcement details of beam specimen.

\subsection{Test Variables}

Twelve beams with various variables are tested in the present study. The test variables restricted to reinforcement type as shown in Table 2 and Fig.3.

Table 2 Beams variables

\begin{tabular}{|c|c|c|}
\hline No. & $\begin{array}{c}\text { Beam } \\
\text { Designation }\end{array}$ & Tension reinforcement \\
\hline 1 & B1S & Steel rebar \\
\hline 2 & B2 & No reinforcement \\
\hline 3 & B3P1 & Plastic rebar Type 1 \\
\hline 4 & B4P2 & Plastic rebar Type 2 \\
\hline 5 & B5P3 & Plastic rebar Type 3 \\
\hline 6 & B6P4 & Plastic rebar Type 4 \\
\hline 7 & B7P5 & Plastic rebar Type 5 \\
\hline 8 & B8P6 & Plastic rebar Type 6+steel bar \\
\hline 9 & B9P7 & Plastic rebar Type 7+steel bar \\
\hline 10 & B10P8 & Plastic rebar Type 8+steel bar \\
\hline 11 & B11P9 & Plastic rebar Type 9+steel bar \\
\hline 12 & B12P10 & Plastic rebar Type 10 \\
\hline
\end{tabular}

All the beams are casting with normal mixture and different ways for forming the PET bottle to use as bars for tension reinforcement. The first beam (B1S) is the reference beam with normal reinforcement for comparing with the remained beams as shown in Fig.(3a). While the second beam (B2) is the Plain concrete beam without tension reinforcement to compare with the other beams which reinforced with PET bars as shown in Fig.(3b). The beams (B3P1) is reinforced with PET bar consists of large PET bottle rolled and fixed with each other with small PET bottle and neck of bottle and filled with plastic box waste as shown in Fig.(3c). The beam (B4P2) with bar consists of large PET bottle and putted inside them small PET bottle as shown in Fig. (3d). The beam (B5P3) with bar consists of large PET bottle rolled and putted inside them small PET bottle rolled too and contacted with each other with neck of bottle as shown in Fig.(3e). The beam (B6P4) with bar consists of small PET bottle rolled and covered in the middle with neck 
of bottle and filled with PVC waste as shown in Fig.(3f). The beam (B7P5) with two layers of large PET bottle cuts into two parts and connected with stirrups and top reinforcement as shown in Fig. (3g).The beams (B8P6 , B9P7 , B10P8 , B11P9 , and B12P10) with hybrid reinforcement which means that the tension reinforcement is consists of steel bars with addition of PET layer with different thickness . The beam (B8P6) consists of steel bras with addition of one layer of large PET bottle cuts into two parts and connected with stirrups as shown in Fig.(3h). The beam (B9P7) with steel bars of $6 \mathrm{~mm}$ diameter and surrounding with large PET bottle rolled around steel reinforcement as shown in Fig.(3i). The beam (B10P8) with steel bars of $6 \mathrm{~mm}$ diameter and surrounding with large PET bottle rolled around small PET bottle that rolled too around steel reinforcement as shown in Fig.(3j). The beam (B11P9) with steel bars of $6 \mathrm{~mm}$ diameter and surrounding with small PET bottle rolled around steel reinforcement as shown in Fig.(3k). The beam (B12P10) is reinforced with fully reinforcement with PET bottle as shown in Fig.(31)

a) B1S

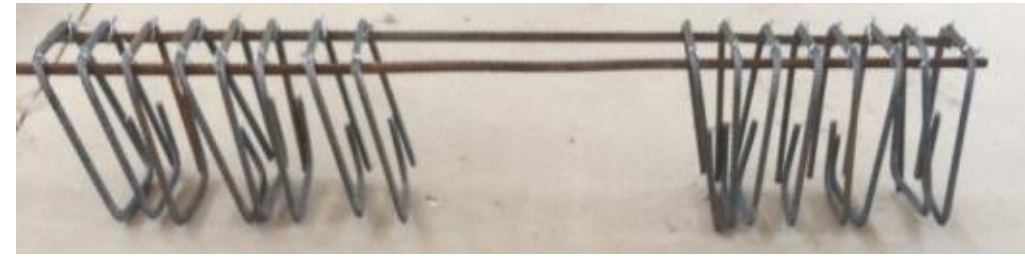

b) $\mathbf{B 2}$
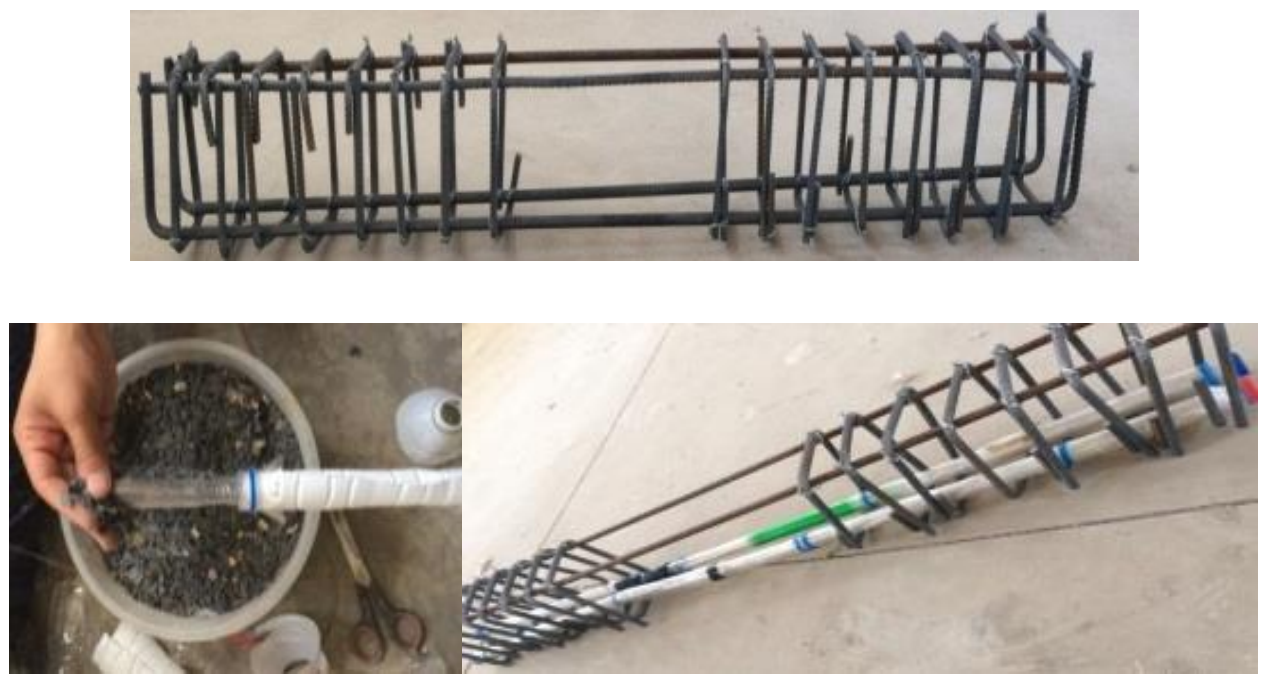

c) $\mathrm{B3P1}$

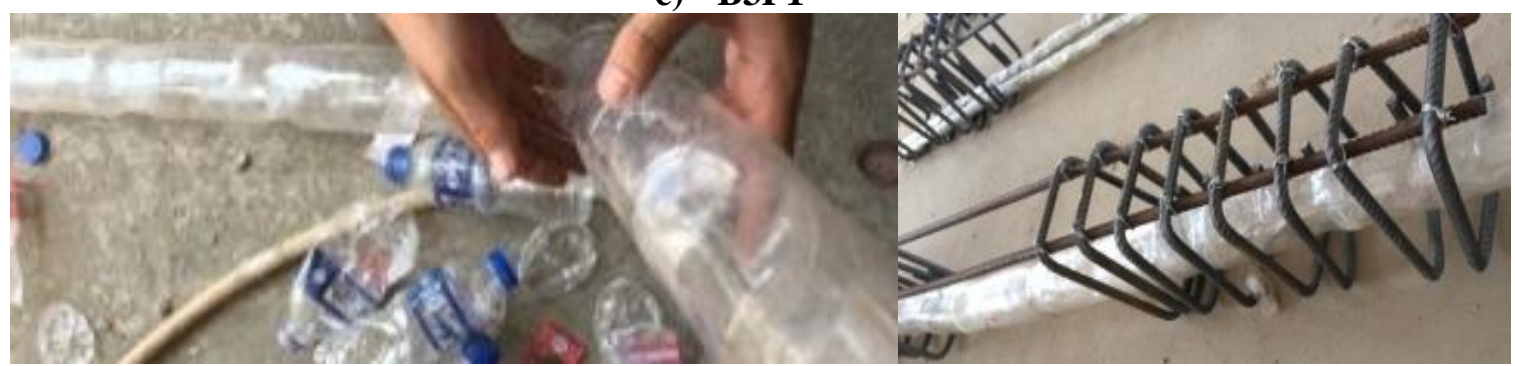

d) $\mathrm{B} 4 \mathrm{P2}$ 
Journal of University of Babylon for Engineering Sciences, Vol. (27), No. (1): 2019.

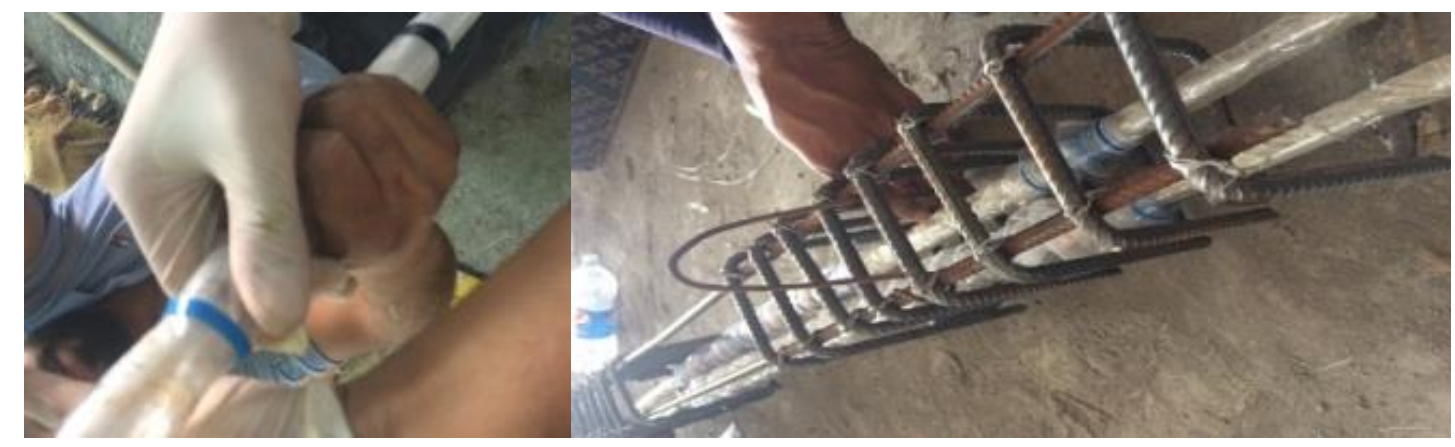

e) B5P3

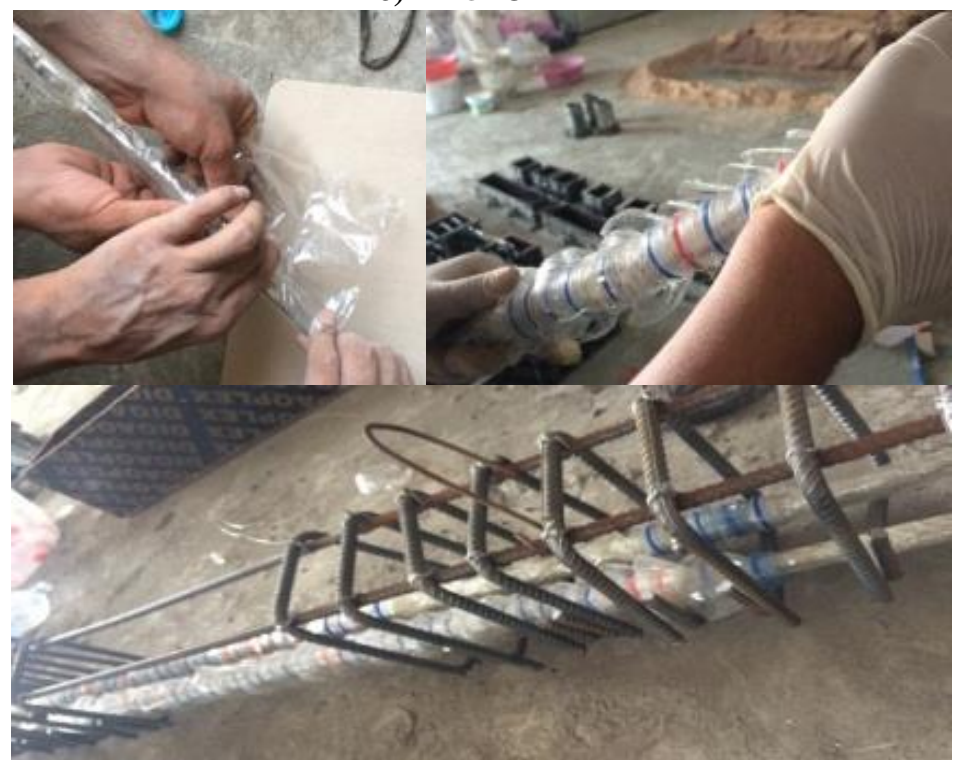

f) $\mathbf{B 6 P 4}$

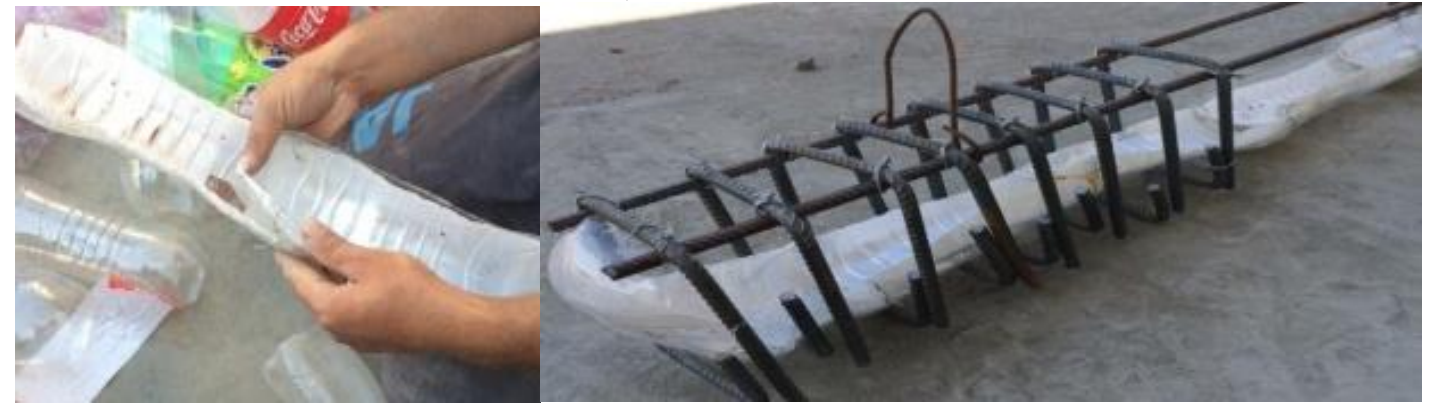

g) $\mathbf{B 7 P 5}$

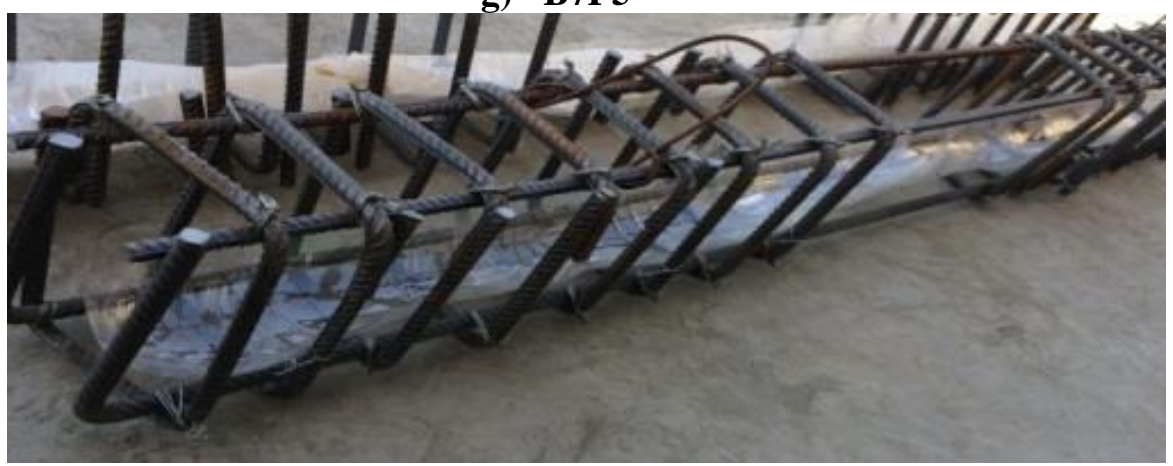

h) $\mathbf{B 8 P 6}$ 


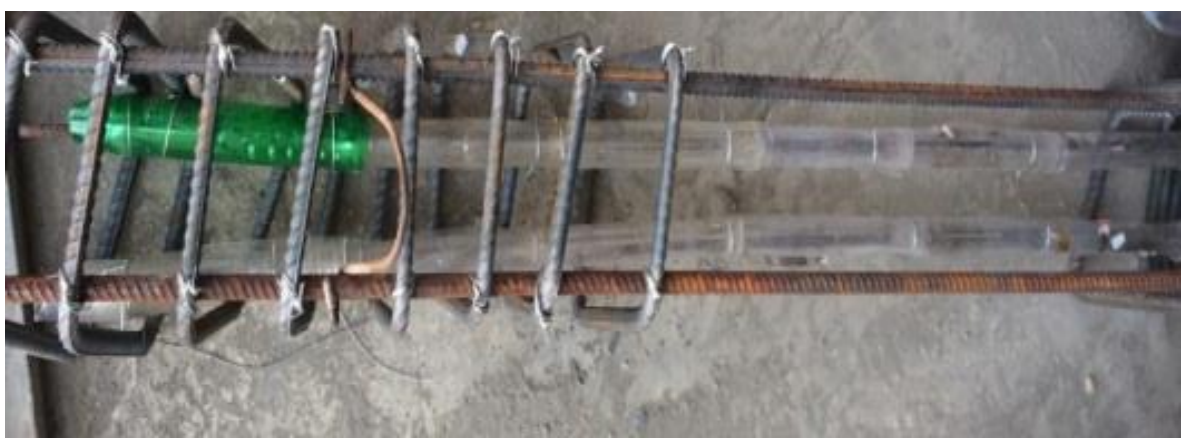

i) $\quad$ B9P7

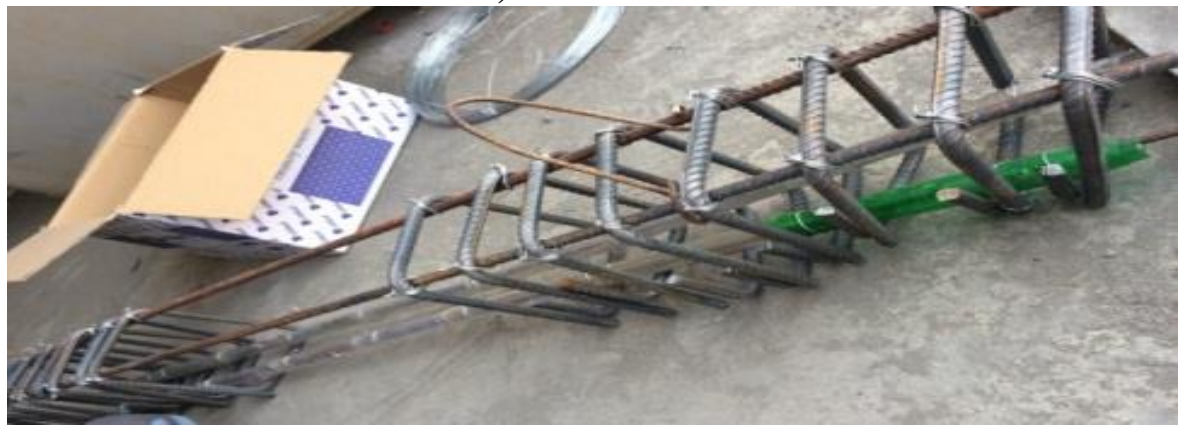

j) B10P8

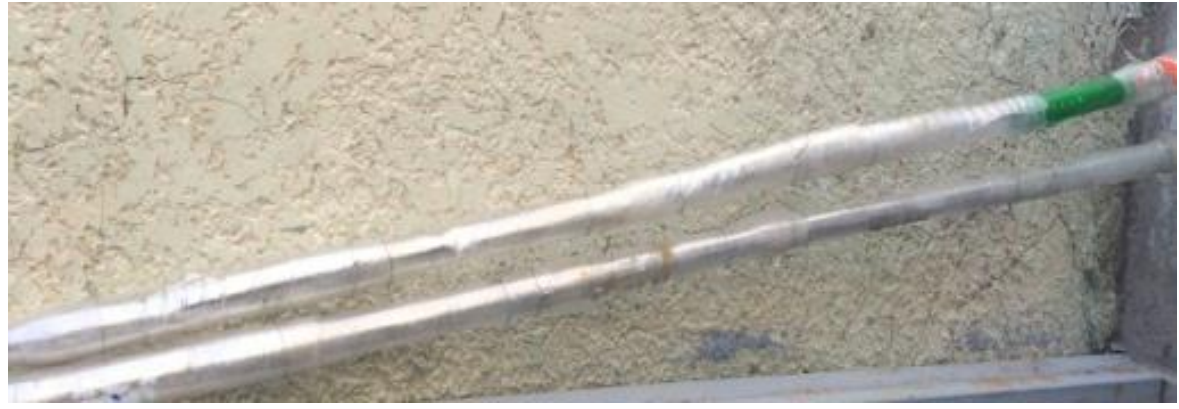

k) B11P9

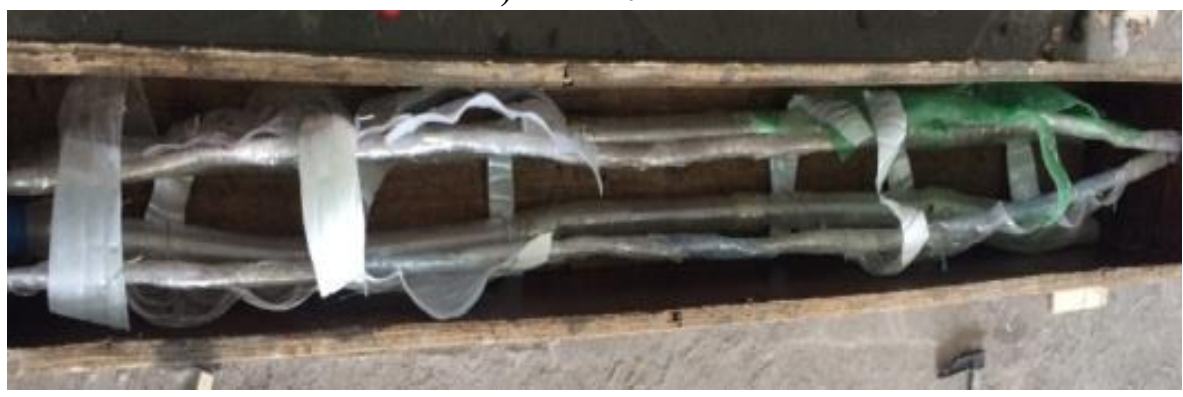

\section{l) B12P10}

Figure 3 Reinforcement details.

\subsection{Testing of Concrete Beams}

A load facility system that available in the structural laboratory of college of engineering in Misan University, is used to test all reinforced concrete beam specimens. Four points loadings procedure is used for all tests as showed in Fig.4. The loads are applied in successive increments of $(5 \mathrm{kN})$ until reach to the failure load. At each load increment, observations are recorded such as the deflection and first crack and draw crack patterns. 


\section{3- Results and Discussions}

The flexural behavior of the concrete beams via ultimate load, the deflection at mid span and crack pattern are investigated. Two reference beams one of plain concrete and the second is reinforced with deformed steel and ten samples with different types of plastic bars are tested. For each load increment, the deflection at mid span is measured and the crack pattern of beams is modified based on crack path growth.

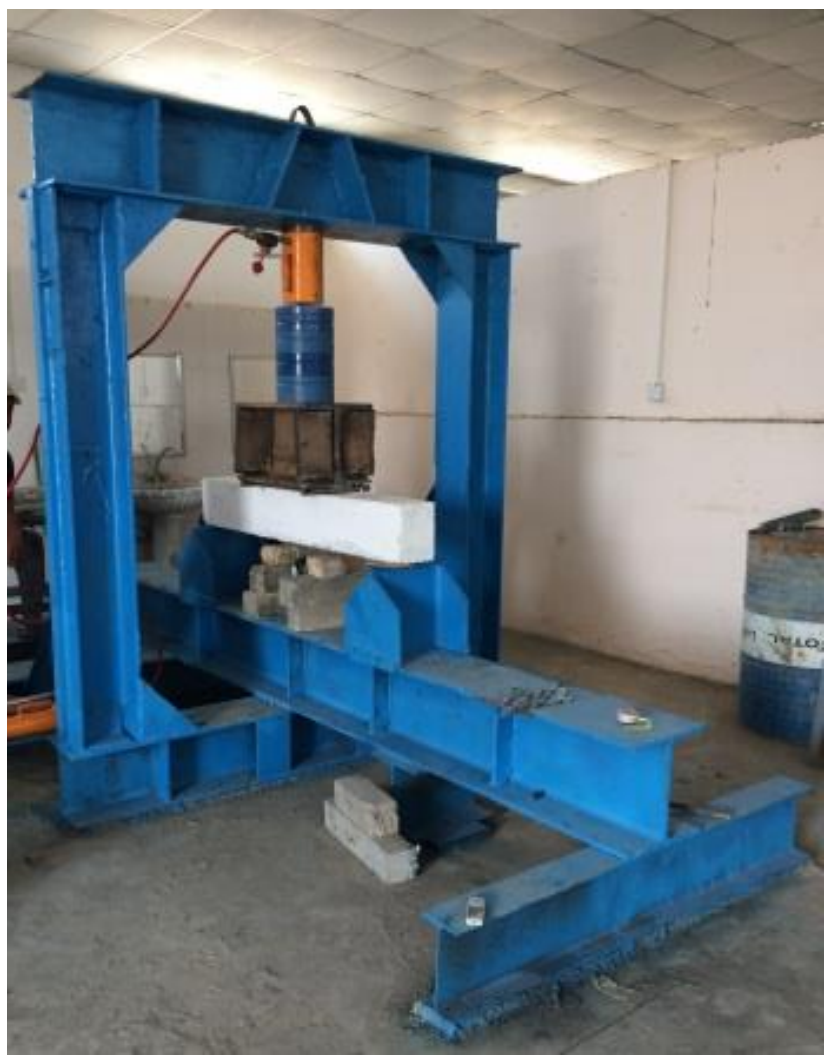

Figure 4 Testing machine.

\subsection{Beam Ultimate Load}

The ultimate load or failure load is the main measurement in the present study. The ultimate failure load of reference beam (B1S) which reinforced with steel deformed rebar is $82.5 \mathrm{kN}$, while the ultimate load for all other specimens are presented in Table.3.. In the present study it's tried to use PET as tension reinforcement in different shapes and configurations, but all presented plastic bars are failed except one case in which the deformed steel bar are used with additional layer of PET bottle cut into two parts, namely beam (B8P6) which yield an ultimate load of $85 \mathrm{kN}$, i.e $3.03 \%$ larger than reference beam. As shown in Table 4, the beams with plastic tension bars presented very small ultimate failure load compared to reference beam, one reason for this results is bonding failure between plastic bars and surrounding concrete in which plastic bars do not participate in resistance tensile forces and just the concrete in tension zone reach to tensile strength its failed. Also it is clear that some specimen with plastic bars show ultimate failure load less than plain concrete, this yield that plastic bars with used configuration became as weak regions or as voids in beam cross section rather than reinforcement. 
Table 3 Ultimate load of test beams.

\begin{tabular}{|c|c|c|c|}
\hline $\begin{array}{c}\text { Beam } \\
\text { designation }\end{array}$ & $P u(k N)$ & 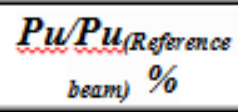 & $\begin{array}{c}\text { Change in } \\
\text { load } \%\end{array}$ \\
\hline$B 1 S$ & 82.5 & 100 & $-\cdots$ \\
\hline$B 2$ & 30 & 36.36 & 63.63 \\
\hline B3P1 & 12.5 & 15.15 & 84.84 \\
\hline$B 4 P 2$ & 15 & 18.18 & 81.81 \\
\hline B5P3 & 15 & 18.18 & 81.81 \\
\hline B6P4 & 20 & 24.24 & 75.75 \\
\hline B7P5 & 20 & 24.24 & 75.75 \\
\hline B8P6 & 85 & 103.03 & 3.03 \\
\hline B9P7 & 25 & 30.3 & 69.69 \\
\hline B10P8 & 30 & 36.36 & 63.63 \\
\hline B11P9 & 30 & 36.36 & 63.63 \\
\hline B12P10 & 15 & 18.18 & 81.81 \\
\hline
\end{tabular}

\subsection{Load-Deflections Curve}

The maximum deflection for all concrete beams are presented in Table 4 and the load-deflection curves are recorded for all beams at mid span as shown in Fig. 5.

As shown in Table 4 and Figure 5, the reference beam (B1S), had the maximum deflection of (12.65 $\mathrm{mm}$ ). Due to bonding failure the deflection measurements for specimens with PET reinforcement could not compared with reference beam, except the case in which a PET layers is used in additional to steel reinforcement in tension zone, namely B8P6, which considerably increase the maximum deflection. As shown in Table 4 and Figure 5 for the specimen B8P6, the maximum deflections is $27.05 \mathrm{~mm}$ which is greater than that of reference beam by about $213.83 \%$. Thus the PET layer improve the beam ductility without any reduction in it's strength.



Figure 5 Load Deflection curves for beams. 


\subsection{Cracking}

The cracking is development in concrete when applied tensile stress exceeding the tensile strength of concrete. The cracking of all beams samples are investigated as shown in Fig.6 the cracking investigation is accomplished via the following topics:

1. First cracking load.

2. Crack pattern.

3. Number of cracks.

Table 4 Maximum deflection of test beams.

\begin{tabular}{|c|c|c|c|c|}
\hline $\begin{array}{c}\text { Beam } \\
\text { designation }\end{array}$ & $\begin{array}{c}\text { Ultimate Load } \\
\operatorname{Pu}(k N)\end{array}$ & $\begin{array}{r}\text { Maximum } \\
\text { deflection } \\
\text { Su (mm) }\end{array}$ & $\begin{array}{c}\Delta \boldsymbol{U} \Delta \boldsymbol{u}_{(\mathrm{Reference}} \\
\text { beam) } \%\end{array}$ & $\begin{array}{l}\text { Changing in } \\
\text { deflection \% }\end{array}$ \\
\hline$B 1 S$ & 82.5 & 12.65 & 100 & -..- \\
\hline$B 2$ & 30 & 4.05 & 32.01 & 67.98 \\
\hline B3P1 & 12.5 & 16.05 & 126.87 & 26.87 \\
\hline$B 4 P 2$ & 15 & 17.05 & 134.8 & 34.8 \\
\hline B5P3 & 15 & 17.05 & 134.8 & 34.8 \\
\hline$B 6 P 4$ & 20 & 20.05 & 158 & 58 \\
\hline B7P5 & 20 & 16.05 & 126 & 26 \\
\hline B8P6 & 85 & 27.05 & 213.83 & 113.83 \\
\hline$B 9 P 7$ & 25 & 30.05 & 237.55 & 137.55 \\
\hline B10P8 & 30 & 29.05 & 229 & 129 \\
\hline$B 11 P 9$ & 30 & 28.05 & 222 & 122 \\
\hline B12P10 & 15 & 16.05 & 126.8 & 26.8 \\
\hline
\end{tabular}

\subsubsection{First Cracking Load $\left(p_{c r}\right)$ for Concrete beam}

The first crack load for all specimens is presented in Table 5 and the graphics of all beams are showed in Fig.6. The reference beam (B1S) and beam (B8P6) showed the same first crack of $35 \mathrm{kN}$ as shown in Table 5. Also its clearly that first crack load of plain concrete (B2) is larger than beam with plastic due to the absence of bonding between plastic bars and surrounding concrete, which made the plastic bars as voids or weak points that accelerate the cracking and then led to early failure of specimens. While the remained beams with PET bars (B3P1, B4P2, B5P3, B6P4, B7P5, B9P7, B10P8, B11P9, $\mathrm{B} 12 \mathrm{P} 10)$ show a decrease in first crack loading by about $(57,64,64,64,64,64,70,57,64) \%$ respectively.

Table 5 First cracking load of tested beams.

\begin{tabular}{|c|c|c|c|c|c|}
\hline $\begin{array}{c}\text { Beam } \\
\text { designation }\end{array}$ & $\operatorname{Pcr}(k N)$ & $P u(k N)$ & $\begin{array}{c}\boldsymbol{P c r} / \boldsymbol{P u} \\
\%\end{array}$ & $\begin{array}{l}\boldsymbol{P}_{c h} / \boldsymbol{P c r}_{\text {(Refe }} \\
\text { rence beam) } \%\end{array}$ & $\begin{array}{c}\text { Changing in } \\
\text { first cracking } \\
\text { load }\end{array}$ \\
\hline B1S & 35 & 82.5 & 0.42 & 100 & -- \\
\hline$B 2$ & 20 & 30 & 0.66 & 57 & 43 \\
\hline B3P1 & 15 & 12.5 & 1.2 & 43 & 57 \\
\hline$B 4 P 2$ & 12.5 & 15 & 0.833 & 36 & 64 \\
\hline B5P3 & 12.5 & 15 & 0.833 & 36 & 64 \\
\hline B6P4 & 12.5 & 20 & 0.625 & 36 & 64 \\
\hline B7P5 & 12.5 & 20 & 0.625 & 36 & 64 \\
\hline B8P6 & 35 & 85 & 0.41 & 100 & - \\
\hline B9P7 & 12.5 & 25 & 0.5 & 36 & 64 \\
\hline B10P8 & 10 & 30 & 0.333 & 30 & 70 \\
\hline$B 11 P 9$ & 15 & 30 & 0.5 & 43 & 57 \\
\hline B12P10 & 12.5 & 15 & 0.83 & 36 & 64 \\
\hline
\end{tabular}




\subsubsection{Cracks Pattern}

The crack patterns for all beams at failure stage are shown in Fig. 6, also the load at which the cracking was started is marked on each specimen. The patterns of the cracks in the reinforced concrete beams are mainly depend on tension rebar. Thus for specimens with PET bars as tension reinforcement, namely beams (B2,B3P1, B4P2, B5P3, B6P4, B7P5, B9P7, B10P8, B11P9,B12P10), they failed with one crack at mid span similar to plain concrete beam due to PET bars are failed by bonding and the beam behaved as beam without reinforcement (plain concrete beam). While for the beam B8P6, the crack appeared in the mid span at tension zone and increased until they reached to the compression zone similar to reference beam B1S.

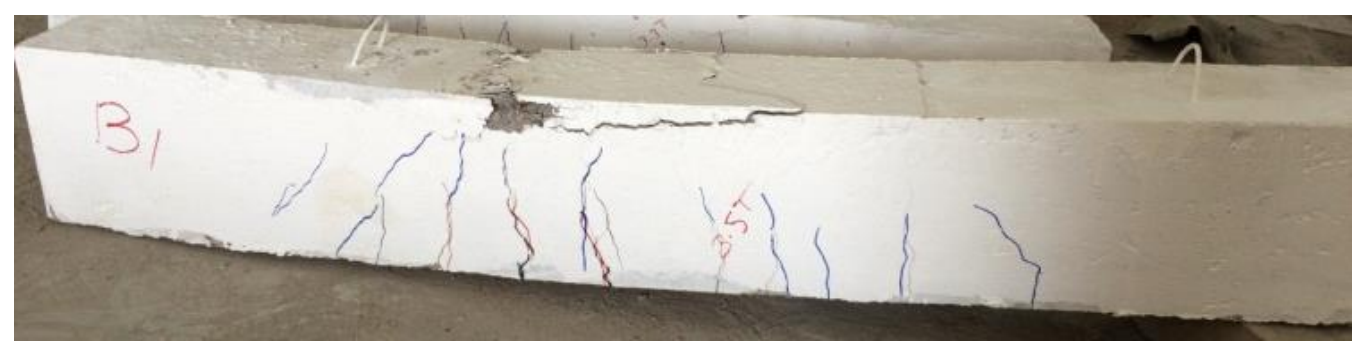

a) B1S

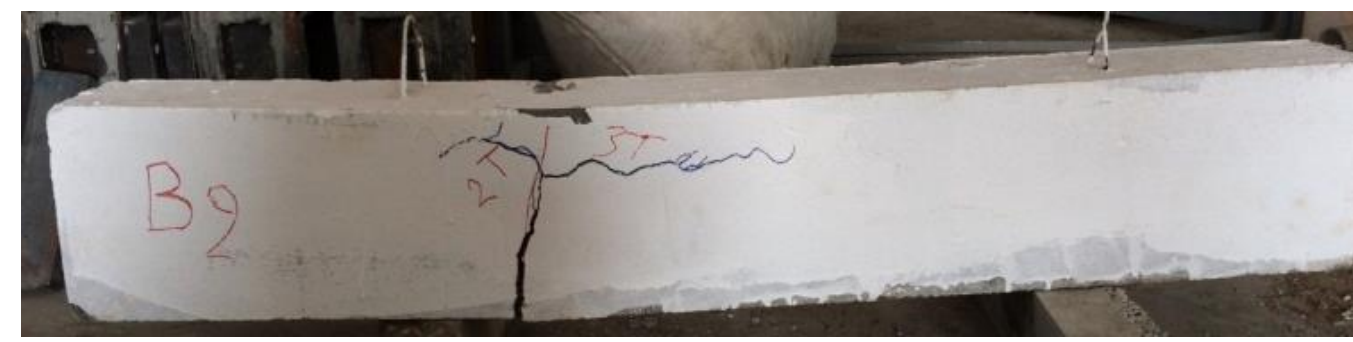

b) $\mathrm{B} 2$

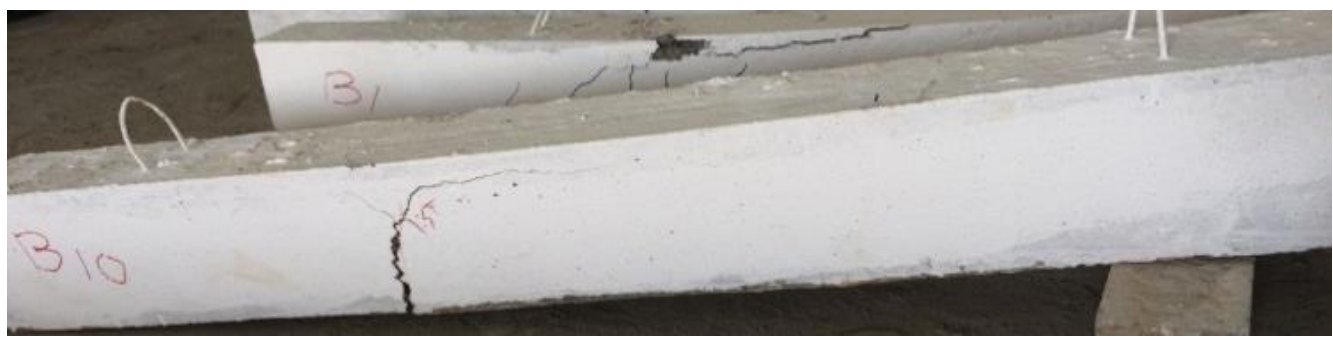

c) B3P1

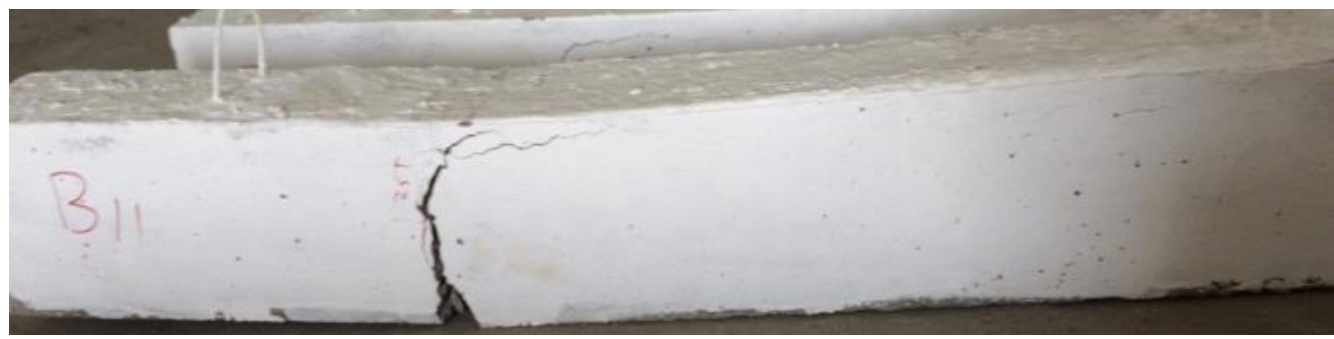

d) B4P2

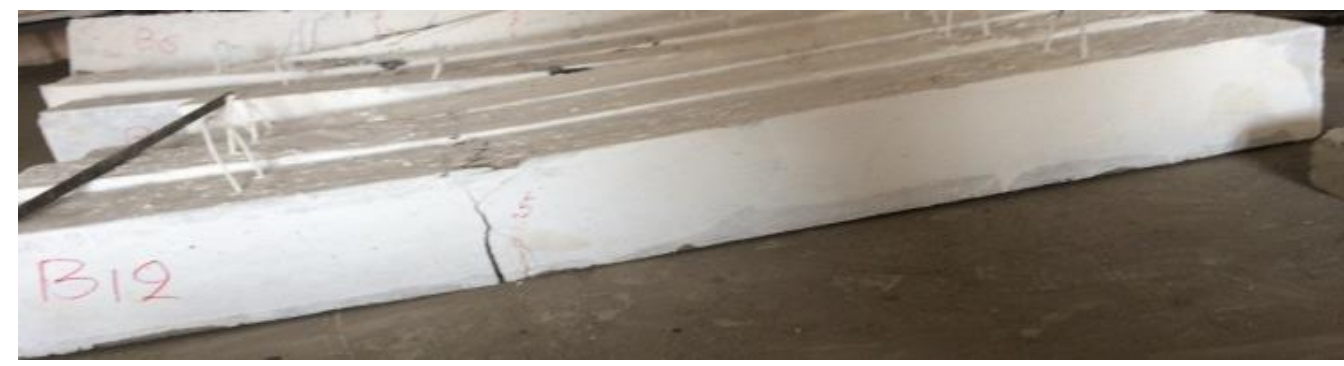

e) $\mathrm{B} 5 \mathrm{P} 3$ 
Journal of University of Babylon for Engineering Sciences, Vol. (27), No. (1): 2019.

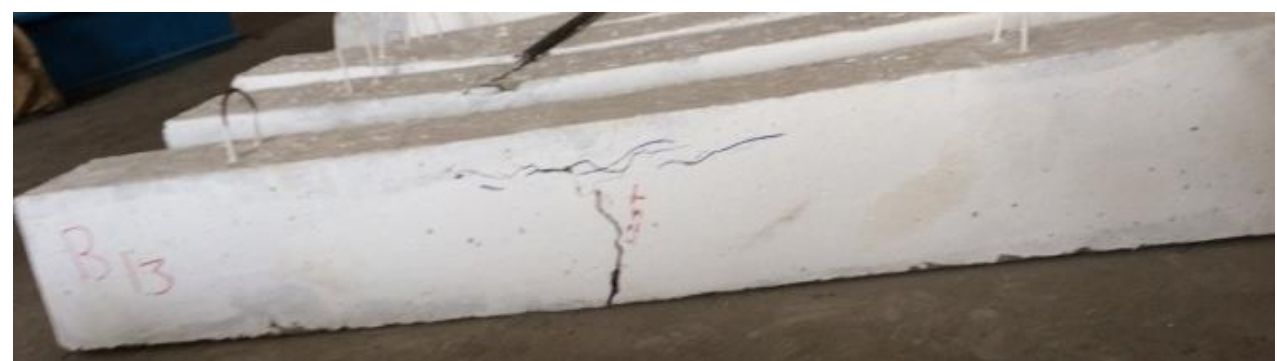

f) $\mathrm{B} 6 \mathrm{P} 4$

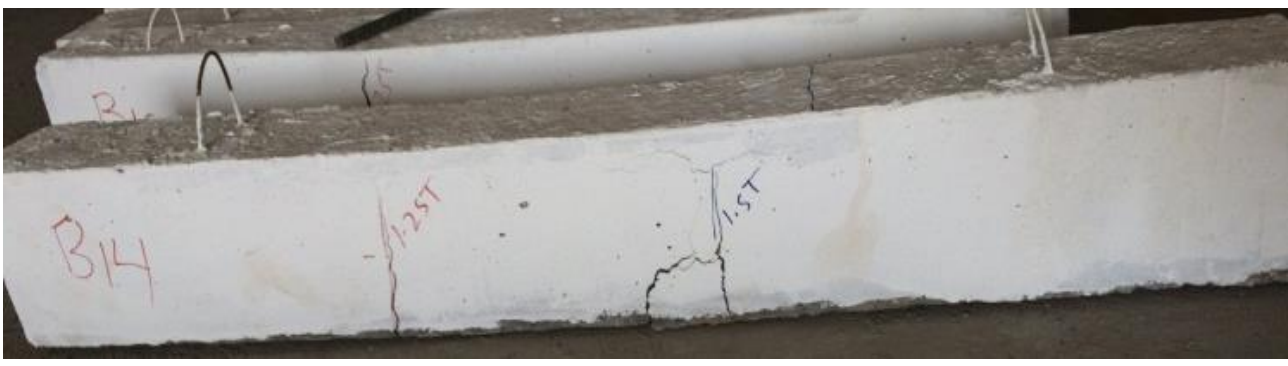

g) B7P5

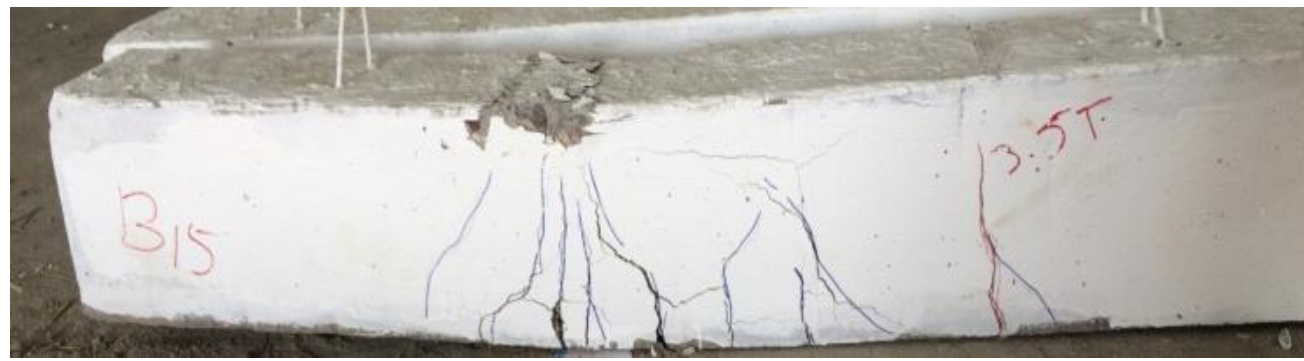

h) B8P6
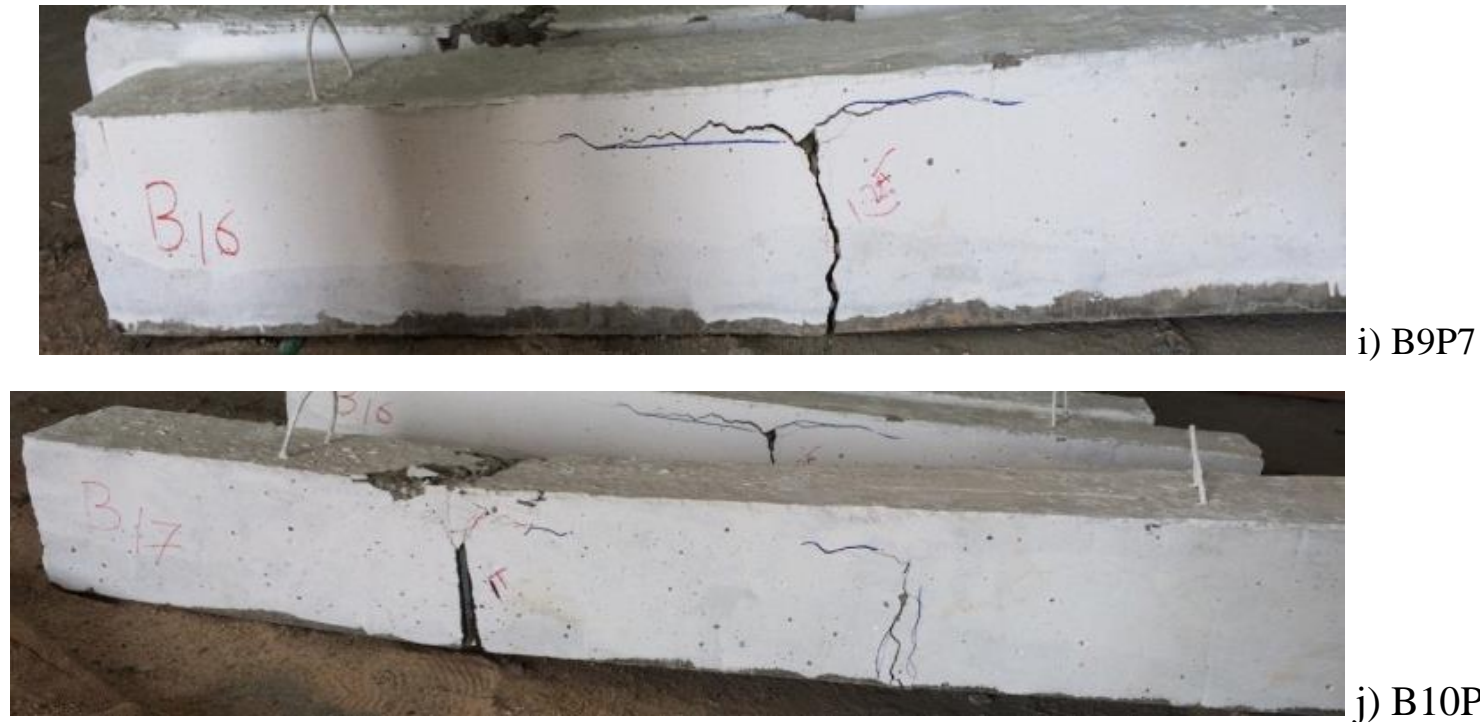

j) B10P8

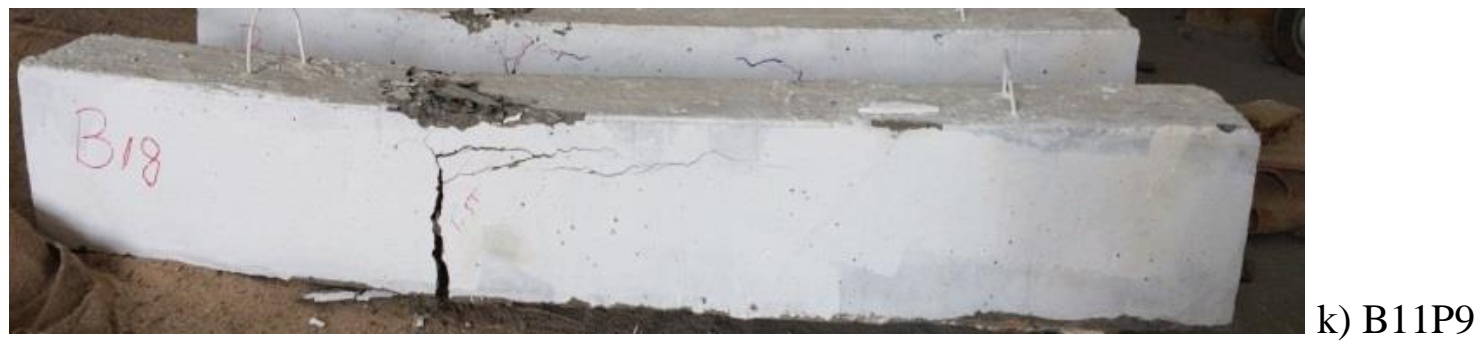




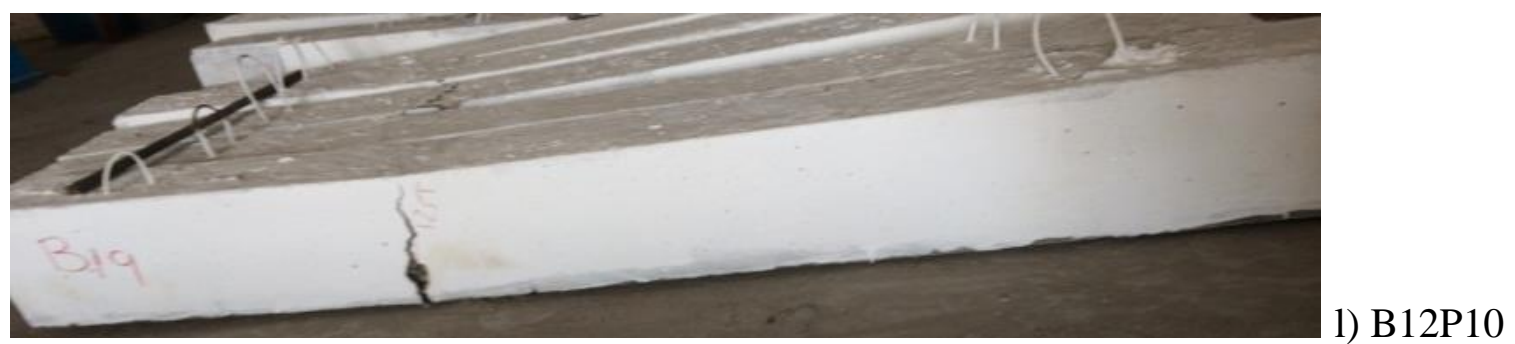

Figure 6 Crack pattern for beams tested.

\subsubsection{Number of Cracks}

The number of cracks varies between one and eleven cracks. The beam (B8P6) had eleven crack, which equal to the number of cracks in reference beam (B1S) i.e., is eleven cracks. While all beams (B3P1, $\mathrm{B} 4 \mathrm{P} 2, \mathrm{~B} 5 \mathrm{P} 3, \mathrm{~B} 6 \mathrm{P} 4, \mathrm{~B} 7 \mathrm{P} 5, \mathrm{~B} 9 \mathrm{P} 7, \mathrm{~B} 10 \mathrm{P} 8, \mathrm{~B} 11 \mathrm{P} 9$, and $\mathrm{B} 12 \mathrm{P} 10)$ that contained on PET bars as tension reinforcement, the number of cracks is one crack, which is the lowest number of cracks compared with the reference beam (B1S) which is eleven cracks.

\section{4- Summary and concluding remarks}

In this study, a comparison between a beam reinforced with deformed bars and ten beams reinforced with PET bars in various patterns as trial of recycling these wastes as tension bars and investigate their effect on the concrete beams behavior, and the following conclusions are drawn.

1. In the present study it's trying to use PET as tension reinforcement in concrete beams using different shapes and configurations, but all presented plastic semi-bars are failed except one case in which the deformed steel bar is used with additional layer of PET bottle cut into two parts, namely beam (B8P6) in which the ultimate load reached to $85 \mathrm{kN}$, i.e, $3.03 \%$ larger than reference beam.

2. Using PET layers in additional to steel reinforcement in tension zone, namely beam B8P6, considerably increase the maximum deflection to $27.05 \mathrm{~mm}$, which is greater than that of reference beam by about 213.83\%.Thus this PET layer improves the beam ductility without any reduction in it is strength.

3. Using PET bars as tension reinforcement with presented configuration and patterns (except beam B8P6) affected negatively on ultimate load of beams and yield ultimate load less than plain concrete due to bonding failure between PET bars and surrounding concrete and made the PET bars as voids or weak region within beam cross section.

4. All presented plastic bars are showed first crack load equal or less than that of plain concrete except beam (B8P6), and they show one cracking pattern at failure of one main crack near mid span, this reflects the reason of early failure of these beams due to the existence of PET bars without enough bonding became as voids or weak region into a beam, which made the beams reinforced with PET bars weaker than plain concrete.

\section{CONFLICT OF INTERESTS.}

- There are no conflicts of interest.

\section{References}

[1] M.W Shaalan., and A.Y. Al-sukani." The Solid Waste and Spatial Variation in Amara City" M.Sc Thesis, Al-Mustansiriya University, Baghdad, Iraq, 2017. (In Arabic)

[2] Plastics Europe "https://www.plasticseurope.org", web Site, Association of Plastic Manufacturers.

[3] Z.Z.Ismail and E.A.Al-Hashmi "Use of waste plastic in concrete mixture as aggregate replacement "Journal of Waste Management, Elsevier, Vol.28, PP.2041-2047, 2007. 
[4] Ms. K.Ramadevi and Ms.R.Manju "Experimental Investigation on the Properties of Concrete With Plastic PET (Bottle) Fibres as Fine Aggregates" International Journal of Emerging Technology and Advanced Engineering, ijetae,vol.2,issue.6 ,June-2012.

[5] P.G.Prabhui, C.A.Kumar, R.Pandiyaraj, Rajesh P. , and L.S.Kumar "Study on utilization of waste PET bottle fiber in concrete " Journal of International Journal of Research in Engineering \& Technology, IMPACT,Vol.2,PP.233-240,2014

[6] E.Rahmani, M.Dehetani, M.H.A.Beygi, H.allahyari, and I.M. Nikbin"On the mechanical properties of concrete containing waste PET particles "Journal of Construction and Building Materials, Elsevier, Vol.47, PP.1302-1308, 2013.

[7] K.S.Kumar and K.Baskar " Recycling of E-plastic waste as a construction material in developing countries " Journal of Materials Cycles and Waste Management, Springer, Vol.17,No.4,PP.718-724, 2014.

[8] P. S.Patil, Mali J.R.Mali, G.V.Tapkire, and H.R.Kumavat "Innovative Techniques of waste plastic used in concrete mixture" International Journal of Research in Engineering and Technology, IJRET, Vol.03, Special Issue. 09, June-2014.

[9] S.Yang, X.Yue, X.Liu, Y.tong“ Properties of self-compacting lightweight concrete containing recycled plastic particles “ Journal of Construction and Building Materials, Elsevier,Vol.84,PP.444-453,2015.

[10] S.B.Kim, N.H.Yi, H.Y.Kim, J.H...J.Kim, and Y.C.Song "Material and structural performance evaluation of recycled PET fiber reinforced concrete "Journal of cement \& Concrete Composites, Elsevier, Vol.32, PP.232-240, 2010.

[11] M.L.A.Kumar, Dr.I.V. Ramana Reddy, and Dr.C. Sasidhar " Experimental Investigations on The Flexural Strength of PET Reinforced Concrete “ Journal of International Journal of Emerging Technology and Advanced Engineering,IJETAE,Vol.4,2014.

[12] F.J. Baldenebro-Lopez, J.H. Castorena-Gonzalez, and J.I. JVelazquez-Dimas " Influence of continuous plastic fibers reinforcement arrangement in concrete strengthened "Journal of Engineering IOSRJEN,Vol.4,PP.15-23,2014.

[13] D.Foti "Use of recycled waste pet bottles fibers for the reinforcement of concrete "Journal of Composite Structures, Elsevier, Vol.96, PP.396-404, 2013. 


\section{التحري العملي لاستعمال مخلفات العبوات البلاستيكية كقضبان شد بالاعتاب الخرسانية المسلحة عباس عودة داود همسة ماهر عدنان \\ قسم الهندسة المننية، كلية الهندسة، جامعة مبسان، العراق \\ hamsamahir95@gmail.com rabbasoda03@uomisan.edu.iq}

يهذف هذا البحث إلى دراسة إمكانية إعادة تدوير مخلفات البولي اثلين تيريفناليت عن طريق تثكيل مخلفات البولي اثثلين

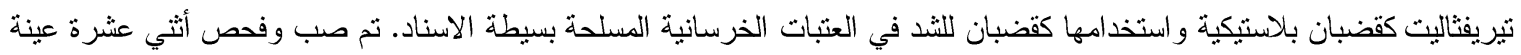

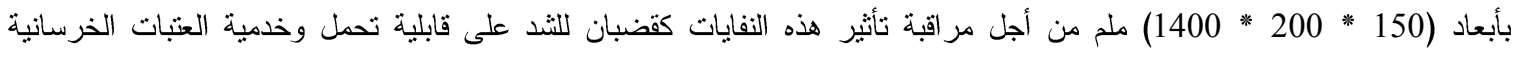

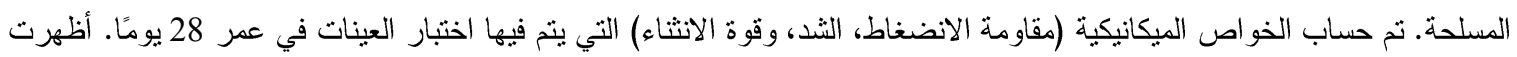

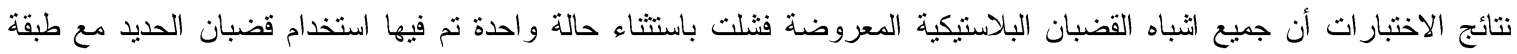

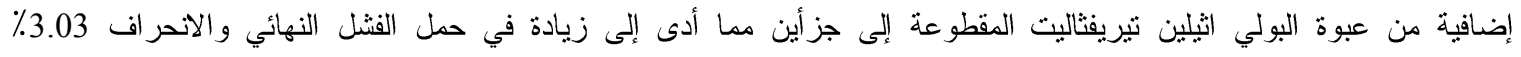

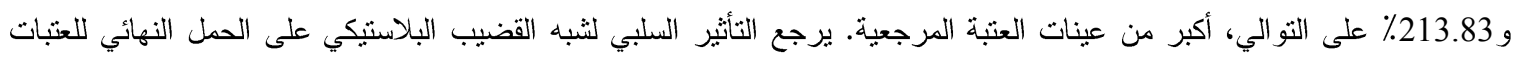

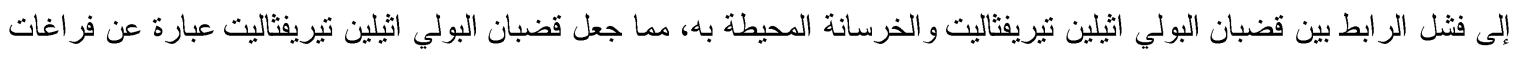
أو منطقة ضعيفة داخل المقطع العرضي للعتبة.

الكلمات الداله: البولي ايثيلين تيريفتاليت، مخلفات البولي ايثيلين تيريفتاليت، شبه قضيب بلاستيكي، قضبان البولي ايثيلين تبريفتاليت، اشرطة البولي ايثيلين تيريفتاليت. 